\title{
LGBT Homeless People, Nomadism and Contexts of Vulnerability to HIVIAIDS
}

\author{
Marcos Roberto Vieira Garcia ${ }^{1}$ \\ Departamento de Ciências Humanas e Educação da Universidade Federal de São Carlos, \\ Sorocaba, Brasil
}

\begin{abstract}
This article aims to reflect on the contexts of vulnerability to HIV/AIDS among the homeless LGBT population, based on field research that sought to analyze their life trajectories, conducted in downtown Sao Paulo. Eleven semi-structured interviews were conducted with homeless LGBT people, four of them with gays, two with lesbians, three with bisexual men, one with a transvestite and a one with a transsexual woman. Analysis showed the presence of a nomadic form of sociability associated with the removal of links with workplaces, the family and school, living on the streets and the frequent use of psychoactive substances, related to heterosexist bias in families, schools and workplaces, but also to a resistance to the ideals of attachment present in these institutions. In relation to HIV/AIDS, this study shows that homelessness is characterized as a condition defined by a synergy of situations of discrimination and violence, strongly related to each other, that increases vulnerability to HIV infection, while hindering the linkage to health services and custody of antiretroviral medication use, preventing adequate treatment in cases of illness from AIDS.
\end{abstract}

Keywords: Homelessness, LGBT, HIV/AIDS.

\section{Diversidade Sexual, Situação de Rua, Vivências Nômades e Contextos de Vulnerabilidade ao HIVIAIDS}

\section{Resumo}

O presente artigo visa a refletir sobre os contextos de vulnerabilidade ao HIV/AIDS entre a população LGBT em situação de rua, a partir de pesquisa de campo que buscou analisar suas trajetórias de vida, realizada na região central de São Paulo. Foram realizadas 11 entrevistas semi-abertas com pessoas LGBT em situação de rua, sendo quatro delas com gays, duas com lésbicas, três com homens bissexuais, uma com uma travesti e uma com uma mulher transexual. A análise evidenciou a presença de uma forma de sociabilidade nômade, associada ao afastamento de vínculos com as instâncias trabalho, família e escola, à vivência nas ruas e ao uso frequente de substâncias psicoativas, relacionada ao preconceito heterossexista nas famílias, escolas e ambientes de trabalho, mas também à resistência aos ideais de fixação presentes nestas instituições. Em relação ao HIV/AIDS, este estudo mostra que a vida nas ruas configura-se como uma situação onde se acumula uma sinergia de situações de discriminação e violência que, fortemente relacionadas entre si, aumentam a vulnerabilidade à infecção pelo HIV, e ao mesmo tempo dificultam a vinculação aos serviços de saúde e a guarda da medicação antirretroviral utilizada, impedindo o tratamento adequado nos casos de adoecimento por AIDS.

Palavras-chave: População de rua, LGBT, HIV/AIDS.

Endereço para correspondência: Universidade Federal de São Carlos, Campus Sorocaba, Rodovia João Leme dos Santos (SP-264), Km 110, Sala 33, Itinga, Sorocaba, SP, Brasil 18052-780. E-mail: mrgarcia@usp.br Agências de Financiamento: Coordenação de Aperfeiçoamento de Pessoal de Nível Superior (CAPES) e Conselho Nacional de Desenvolvimento Científico e Tecnológico (CNPQ). 


\section{EI Nomadismo y Contextos de Vulnerabilidad al VIH/SIDA entre la Población LGBT Sin Hogar}

\section{Resumen}

En este artículo se pretende reflexionar sobre los contextos de vulnerabilidad al VIH/SIDA entre la población LGBT sin hogar, con base en una investigación de campo que intentó analizar sus trayectorias de vida, que se realizo en el centro de São Paulo. Se realizaron 11 entrevistas semi-estructuradas con personas LGBT sin hogar, cuatro de ellas con gays, dos con lesbianas, tres con hombres bisexuales, una con una travesti y una con una mujer transexual. El análisis mostró la presencia de una forma nómada de sociabilidad asociada con la eliminación de los enlaces con el trabajo, la familia y la escuela, la vida en las calles y el uso frecuente de sustancias psicoactivas, en relación con el sesgo heterosexista en las familias, escuelas y los lugares de trabajo, sino también con la resistencia a los ideales de la fijación presente en estas instituciones. En relación con el VIH/SIDA, este estudio muestra que la vida callejera se caracteriza por ser una condición definida por una sinergia de las situaciones de discriminación y violencia, fuertemente relacionadas entre sí, que aumenta la vulnerabilidad a la infección por VIH, mientras que dificulta la vinculación con los servicios de salud y la custodia del uso de medicamentos antirretrovirales y la prevención de un tratamiento adecuado en casos de enfermedad de SIDA.

Palabras clave: Población sin hogar, LGBT, VIH/SIDA.

This article aims to promote reflection about the contexts of vulnerability to HIV/AIDS among homeless lesbians, gays, bisexuals, transvesites, and transexuals (LGBT) drawing on field work carried out in downtown São Paulo that sought to analyze their life trajectories. We introduce the relevant literature on our population of focus, which is predominantly produced in countries other than Brazil, and we follow the themes of urban nomadic experiences associated with homosexuality and HIV/AIDS among the homeless, which is important for later reflections made in the article. A greater propensity for LGBT people to be homeless and the specificity of their experiences with homelessness and institutions of belonging is still an understudied topic in Brazil, but it is something that has been observed consistently in international studies.

Studies in the United States about homeless youth consider them as a segment of the population of youth that live in the streets or that live in shelters, and sometimes include young adults close to their 30s. This segment receives the greatest attention in United States-based studies related to sexual orientation and homelessness. In large cities in the West Coast of the United State, the proportion of all homeless youth who identified as being LGBT is approximately $20 \%$ (Co- chran, Stewart, Ginzler, \& Cauce, 2002; Kennedy, 1991; Unger, Kipke, Simon, Montgomery, \& Johnson, 1997). The main factor explaining this high proportion is the fact that LGBT (lesbian, gay, bisexual and transgender) youth are much more likely to be expelled or to run away from home at an early age than their heterosexual counterparts, leading many to live in shelters or on the streets (Hyde, 2005; Rew, Whittaker, Taylor-Seehafer, \& Smith, 2005; Whitbeck, Chen, Hoyt, Tyler, \& Johnson, 2004).

The North American literature also shows some particularities of homeless LGBT youth when compared to those who identify themselves as heterosexual: they have a life history with more physical and sexual violence in their families of origin and while they are homeless (Whitbeck et al., 2004); they are more likely to abuse alcohol and illegal substances (Cochran et al., 2002); they are more subject to discrimination perpetrated by other homeless youth and by the police (Milburn, Ayala, Rice, Batterham, \& Rotheram-Borus, 2006); they have a significantly higher number of sexual partners (Cochran et al., 2002); they more often practice survival sex - the exchange of sexual acts for drugs, food, shelter or money (Whitbeck et al., 2004); they are more likely to enter commercial sex work (Kruks, 
1991; Pennbridge, Freese, \& Mackenzie, 1992); and they are more vulnerable to HIV infection (Kipke, O’Connor, Palmer, \& Mackenzie, 1995; Pfeifer \& Oliver, 1997; Rotheram-Borus \& Koopman, 1991; Sondheimer, 1992; Sugerman, Hergenroeder, Chacko, \& Parcel, 1991).

In a study conducted in England, Dunne, Prendergast and Telford (2002) observed a history of childhood violence, drug abuse, sex work, and interrupted school (many times a result of the lasting and intense bullying they experience) among this segment of the population, and they show that for more than one-third of their sample, sexual identity was the "trigger" for the family crisis that led youth to leave their homes. Twothirds of LGBT homeless youth who participated in a study conducted by Rosenthal, Mallett and Myers (2006) in Australia, identified conflicts with their parents as the only important reason do leave their home of origin.

Issues related to sexuality have been brought up in some Brazilian studies on homelessness. Escorel (1999) cites the reports of two of her informants who estimated that $60 \%$ of homeless men from Rio de Janeiro have homosexual relations, which would be motivated by the "lack of affection they feel on the street and a living situation that is almost exclusively masculine" (p. 165), besides the possible exchange of sex for money. De Lucca (2007) in a study in which participant observation was conducted in a male shelter in São Paulo refers, in passing, to the fact that there is much "dating and sex, although there is a strong prejudice against homosexuals" (p. 218) and notes the constant noise of sex in the male dorm at night. Frangella (2004), in research conducted in the Brás neighborhood in São Paulo, noted the presence of effeminate homosexuals that "appeared on the streets and in the cafeteria, with some prominence, however discrete. They used earrings, tidy hair, some treated with gel. They wore tight pants and shirts, but without exaggeration" (p. 171). Apart from the stigmatization that was directed toward them in some moments, she observed that it did not impede their situation of living together with others and that

homosexuals share bonfires, booze, food, and are part of other everyday sociability of the street. They are also included because of their feminine qualities: being caring, warm, and gentle. They are included in the status of women, even with regard to sexual satisfaction. Many homosexuals had husbands in the street... On the part of men, the manifestations of libido are... telling when associated with their male partners or homosexuals "under the covers". (p. 198).

The same author observes, like Escorel (1999) that although homoerotic sexual practice is widespread (estimated by the coordinator of the cafeteria where she carried out the research to be practiced by $80 \%$ of homeless people using the shelter), it does not mean that the majority of those who practice homosexual acts identify as LGBT and that in "the absence of women, drunk and under the blankets of intimacy, men give up their affection to other men, even if it is little assumed" (Frangella, 2004, p. 219).

\section{Homelessness, Homosexualities, and Nomadic Lifestyles}

Some studies in the field of the social sciences that reflect on the issue of displacement of people through different geographical spaces make use of the term "nomadism" as a category that transcends mere displacement, becoming a way of life with its own characteristics and/or as a characteristic typical of "postmodern" life experiences. In fact, if we consider that the current period is a time of historic fragmentation of identities of gender, sexuality, ethnicity, race and nationality, those which were most defining of social stability (Hall, 2003), subjects potentially become freer when faced with the possibilities of formation and rupture of bonds of all orders, therefore becoming more mobile. Examples of arguments that relate nomadism not only with geographic dislocation but also with a type of subjectivity are seen in the works of Deleuze and Guattari (1995) and Maffesoli (2001).

Maffesoli (2001) reflecting critically on the concept of Durkheimian anomie, considers this condition as something structural and not necessarily negative. Nomadism appears thus as a condition antithetical to a sedentary lifestyle, which is committed to the ideas of residence, security 
and domestication. Condition par excellence of modernity, sedentariness appears as an offshoot of the State in everyday life, where the fixing of oneself appears as an instrument of domination. Nomadism, assuming multiple identifications and also multiple locations, configures a break from this modern ideal.

From the analysis of nomadism carried out by Deleuze e Guattari (1995), this concept appears in a positive form as a condition likened to an idea of an open future to be constructed without a program and related to the Nietzchean notion of "becoming." In nomadism the model for group formation is the band, which has as some of its characteristics the absence of a consolidated and stable power, transitoriality and turnover, and which causes the persons of these groups to disband and group again. In sedentary lifestyle, on the other hand, the dominant social order of the capitalist society that has the family as its model, par excellance, individuals are restricted by identities in more well defined social organizations. Nomadism appears as a possibility for heterogeneity as opposed to stability and constancy, as a way of escaping their identity restrictions, typical of capitalism. A very intriguing analysis by Guattari (1992) takes the view that capitalism also creates a "false nomadism", a simulation in order to protect against the true nomadism, a process that can be observed in metropolitan living, where apparently everything circulates (people, cars, music, fashion, etc.), but at the same time everything seems to be fixed and immovable.

Nomadism has also received attention in studies on homeless people. However, there is disagreement as to whether the alleged freedom that accompanies it is "real" in the sense of corresponding to a resistance movement against the norms associated with the connection with work or with family, or if it is illusory, corresponding to a denial of the possibility of maintaining such links (and not in resistance to them). Escorel (1999), while agreeing that nomadism is a marked feature of the homeless population - be it because this involves frequent migration from one city to another or because of the continuous dislocation through the city's public spaces - is quite critical of the analyses that nomadism as something intrinsic to the nature the homeless, as if it were ultimately a choice, and she considers their nomadism much more as an imposition of poverty and flows of circulation around cities. In this sense, she does not see the street as an area of freedom, but as the "space of unpredictable insecurity and vulnerability and of the constant danger that lurks" (p. 185).

We consider it important to take into account here that the lived experiences of nomads can be understood in the case of homelessness as associated with a twofold process: resistance against the ideals of residence, security, stability and constancy, but also vulnerability to many forms of violence that exist in this context. To approach them from a point of view that is exclusively positive, of a disruption that subverts the disciplining of bodies and subjectivities, or negative, based on the ideas of lacking, needing or suffering, implies an impoverishment of interpretative possibilities of their experiential universe.

The relationship between nomadism and homosexuality has been explored by some authors in Brazil. Perlongher (1987) observed the presence of a model of nomadic socialization among male sex workers in São Paulo. Separation from the family of origin and experience with a "group of friends" is cited as common by Green (2000) in relation to the universe of Brazilian homoerotic experiences in the second half of the twentieth century. Parker (2002), in his analysis of LGBT migration in Brazil and worldwide, shows that the pursuit of sexual freedom is not the sole reason for the search for the "big city", although the escape from the surveillance in smaller towns is also an important factor. The quest for prosperity and modernity, also present in other migrant groups, are factors to be highlighted in sexual migration: even if individuals remain poor, diversity and speed of life in big cities are preferable for many homosexuals who come to them.

If nomadism is a prominent feature of both the trajectory of people on the streets as much as of many that relate to each other in a homoerotic way, it is pertinent to consider its relation to the lived experiences of LGBT people living in the street in our study. More important than thinking 
about the "sum" of the factors that make this possible, however, is looking at how the factors relevant to each of these experiences are articulated in the lives of these people, and more specifically, to reflect on the links between time and space lived by them.

Reflecting on the strengthening of bourgeois nuclear family model since nineteenth century in Europe, Perrot (2009) draws a parallel between this family model and the sedentary condition. The centrality of the figure of "father" in nineteenth-century France, which replaces the authority of the king in the home environment, shows the misconception of considering the private space the domain of women, as the "father" also dominates the home, even while he is not physically present. At the same time, however, young men are gradually allowed to live a period of freedom from the demands of family constitution and "to live youth" before marriage makes them sedentary. This "institutionalized nomadism" is offered by the author even for young men of the lower classes, at the moment when the first groups ("tribes") were formed.

Perrot (2009) draws parallels between nomadism in youth and in the bohemia of the artists of the time - a relatively accepting space for those considered pederasts - which is important to discuss here to permit reflections about spaces for leisure for LGBT youth. For her, both provisionally nomadic youth as much as more permanently bohemian artists have in common a symmetrical inversion with respect to bourgeois life, which occurs in relation to time (night), space (streets and bars), types of housing (uncertain) and his morality (not based on fidelity). Are these pillars of "urban nomadic life" - night time, open spaces, uncertain housing and relationships without commitment - also common in certain homosexualities that exist in poorer socioeconomic strata, as in the case of brazilian LGBT people living in the streets?

\section{Health Problems and HIVIAIDS among Homeless LBGT People}

Living in a universe where there are frequent cases of violence and deprivation, poor diet, poor hygienic conditions, lack of privacy, direct exposure to thermal variations and the imperative of daily seeking for resources for survival leads to a substantial increase in vulnerability to health problems in the homeless population as a whole. Among the diseases prevalent in this segment in Brazil, are sexually transmitted diseases, including AIDS, skin diseases, especially ulcers and dermatitis, respiratory diseases, especially pneumonia and tuberculosis, hypertension, and neuropsychiatric disorders, in particular epilepsy, addiction to alcohol and other psychoactive substances and psychosis (Carneiro, Nogueira, Lanferini, Ali, \& Martinelli, 1998; Costa, 2005; Lovisi, 2000; Silva, 2000). The high prevalence of mental disorders in this population seems to follow the logic of the "vicious cycle": some disorders such as addictions, mental health problems and psychosis are predisposing factors in relation to homelessness where there is no adequate psychosocial support. But homelessness also contributes to the emergence or worsening of these disorders, as pointed out by Dantas (2007).

Some studies show peculiarities in this segment of population in relation to health care. In the discourses of health professionals interviewed by Carneiro et al. (1998), one of the elements raised is that of the people in this situation only recognize themselves as sick if their ability to walk around town is undermined, as this impedes survival, which depends on access to feeding sites, which are distant from each of other in a city like São Paulo. Dantas (2007) also observes that many of them only seek medical treatment in emergency situations, including trauma, sudden onset of severe symptoms or more advanced stages of illness. Treatments that require a greater adherence to medicines and health services, as is the case for involving tuberculosis and AIDS are particularly made difficult among this segment, which leads to a sharpening of these diseases and the possible infection of others living in the same conditions.

The homeless population in Brazil, as in North America, has been identified as highly vulnerable to HIV infection precisely because of amplification of economic misery that we observe in it, a fact that adds to the common abuse of psychoactive substances, the lack of perma- 
nent housing and marginalization and violence to which the homeless are submitted (Malta, Petersen, Clair, Freitas, \& Bastos, 2005). Recent research in Brazil has shown a higher prevalence of HIV/AIDS in this population. Brito, Parra, Facchini and Buchalla (2007), in research done with clients of a night shelter in São Paulo detected a prevalence of $8.5 \%$ of the hepatitis $\mathrm{C}$ virus, $30.6 \%$ of previous hepatitis B infection, $3.3 \%$ of acute or chronic infection by hepatitis B virus, $5.7 \%$ of syphilis and $1.8 \%$ of HIV - a rate more than three times that of the adult Brazilian population, estimated at .5\% (Joint United Nations Programme on HIV/AIDS [UNAIDS], 2006). In the First National Census and Sample Survey on Population in Homeless (Meta Instituto de Pesquisa de Opinião, 2008), 1.5\% of respondents claimed to be living with HIV/AIDS. Considering that many people do not know they are carriers and the stigma associated with coming out as infected, this number is certainly underestimated.

\section{Methodology}

The population addressed in this qualitative study consisted of homeless people who identified themselves as LGBT or related terms, such as "homosexual", the identity most self-reported in classes living in poverty. The fieldwork began with an initial step of mapping the places frequented by this segment of the homeless population. This mapping was facilitated by the fact that one of the researchers had been involved in a community agent program in the area of social assistance in central São Paulo, knowing these places of concentration. Because the fieldwork was carried out during winter, which causes people that regularly roam the streets to remain in more enclosed spaces in order to protect themselves from the cold, there was difficulty in contacting potential respondents for this research directly in streets, their place of stay or temporary housing. For this reason, we chose to conduct interviews in shelters as an alternative field method. Because of greater openness to perform this part of the fieldwork, we selected a shelter in the central region of São Paulo from which we formally requested the authorization to carry out research with its users. Eleven semi-structured interviews were conducted with informants who gave informed consent: four were gay, two were lesbians, three were bisexual men, one was a travesti, and one was a transgender woman. These categories were established by grouping the self-identities of the study participants (i.e., those who identified as homosexuals were grouped in the categories "gay or lesbian"). The age of the informants ranged from 20 to 39 years of age. We invited participants to be interviewed because they knew the community agent who was part of our research team, they were introduced to us by a staff member of the shelter, and they were referred to us by some of the first informants interviewed.

The interview followed an interview guide, which included questions about: family of origin during childhood, the process of education, relationships with the community (with neighbors, etc.) during childhood, possible early sexual experiences, insertion into the workforce and professional trajectory, crises and possible ruptures in their families of origin, affective and sexual life during adolescence and in the present, licit and illicit substance use, friendship ties and networks of socialization since their adolescence, ways to cope with unemployment and strategies for survival, resources that provided assistance, health care, the practice (or not) of safer sex, relationships with other people living in the streets, and illicit activities as a resource for survival.

Our interviewing strategy established an effective dialogue with the population studied, maximizing interactive and relational context in obtaining data through a horizontal relationship and an attitude of respect for research subjects, as a way to investigate life trajectories of respondents. The interviews were audio-recorded and transcribed.

This study was approved the Ethic Committee for Research on Human Subjects of Universidade Federal de São Carlos (UFSCar), and it followed the ethical parameters of research with human subjects according to Resolution $\mathrm{n}^{\circ}$ 196/96, of the Brazilian National Health Council, which includes the necessary documentation of informed consent given by those involved (from those interviewed and from the institution 
from where they were recruited) and care with anonymity.

As an analytical framework, we used categorical content analysis as proposed by Bardin (2004), which is characterized by the classification of elements for analysis according to thematic differentiation and a subsequent regrouping by similarities established between them. Categorization permits, in this way, to condense raw data into simpler representations, which allows for the establishment of interpretative inferences. This connection to the central idea, thus in search for greater visibility of the data, facilitates the process of drawing relationships between them and the theoretical framework. The analytical work sought to identify common elements in the trajectories of the subjects in order to configure the social trajectory of the group we were investigating. There were several elements considered important to mapping this trajectory: relationship with the family of origin during childhood, the process of education, perceptions of homoerotic desires, possible conflicts resulting from these perceptions, insertion into the workforce and professional trajectories, possible crises and ruptures with the families origin, affective and sexual life during adolescence and presently, the abuse of licit and illicit substances, friendship ties and networks for socialization since their adolescence, ways to cope with unemployment and survival strategies, resources and entities that provided assistance, health care, the practice (or not) of safer sex, interactions with other LGBT people living in the streets, relationship with other segments of the population living in the streets, and illicit activities as a resource for survival, lived experience with discrimination related to homosexual or bisexual orientation or transgender identities.

\section{Results and Discussion}

\section{Life Trajectories}

Family conflicts related to the rupture with heteronormative patterns were identified as determinants for homelessness for a significant part of the research informants. This separation was lived by some in a direct way - in the form of outright expulsion - and by others indirectly, from the perspective that coming out would disappoint the family, which ultimately generated distance from the family:

"Parents do not understand, because it's not a thing, which, it is not normal in the eyes of others, because only those in GL [gay and lesbian] world knows the deal, people who are not cannot begin to imagine" (Wilson, bisexual, 20 years).

"For me, I was going through something negative with my family. I think that my mother did not feel well because I was homosexual... then, I wanted to leave" $\left(\mathrm{Nega}^{2}\right.$, gay, 32 years).

The separation from family of origin was associated by informants to the lack of family support in times of financial instability, which in turn was seen as a determining factor for current homelessness. In two cases, the situation of the death of the parents led the family to disengagement in relation to this support, motivated by prejudice against homo/bi/transsexuality on the part of the family:

My uncles sold the house [of the father of the interviewee, who died] and they disappeared... They came one day with a guy who bought it and said: "Look, you are no longer the owner of this house, neither are we, the house is his, you are in the streets, and we are not going to help you out because you are homosexual". (Tirso, bi, 22 years)

Family is father and mother, so when the father and mother die, there the situation gets more complex, because no relative will want to get involved... that we continue to manifest ourselves, talk about living in the streets, but even then people prefer not to participate. Interviewer: Do you think this has to do with you being trans? Mariana: It has to do with it, yes. (Mariana, transgender woman, 37 years)

The investigation of educational trajectories also reveals frequent scenes of discrimination

2 Nega's original social name also alludes to Afrodescendence. 
suffered by informants in the study, even though they sometimes did not clearly relate to them as a result of prejudice:

"In school, it was this story of 'Maria-João'. I never liked going to school, many times I had physical fights with boys, I had physical aggression and exchanged offenses, and that left me hurt" (Luísa, lesbian, 22 years). In school, I never had a little group of my own, because I had a lot of shame and because when I clung to people, the kids would say... "ah, why are you gay", this left me crazy, I really didn't like it. (Wilson, bi, 20 years)

The professional trajectory of the informants was also marked by a context of heterosexism in the workplace, especially in cases when gender performances suggested possible homosexuality. Those who managed to maintain a heterosexual "appearance" could circumvent discrimination in these contexts, which for some was lived as a painful process of assuming a heterosexual appearance:

"Thank God I don't appear to be gay. Really, it would be much easier for me to get a job" (Rogério, bi, 29 years).

I cannot ask for the service, because she [the employer] is going to look at me and say: "How is a lesbian woman going to work in the middle of a bunch of women?" So I have to make that transformation. That is horrible, I can't be myself. (Elaine, lesbian, 38 years)

I cannot look for work in jeans and a shirt; I have to wear preppy clothing. I don't like it, it makes me uncomfortable, but that's how it has to be... I worked as an intern once, my boss said, "don't come looking totally like a man”. (Luísa, lesbian, 22 years)

Insertion in the commercial sexual market, be it in a casual sense or for longer periods of time, was also cited by several informants, and it was related to the difficulty of having another option:

Interviewer: "You can here [to São Paulo] already thinking of doing sex work or..." Nega: "No, unfortunately that was my only option, right?" (Nega, gay, 32 years).

There were three men who were not living together, they were playboys, a slang term, and they came from another place, they spoke a clear Portuguese, asked a direct question, they named the price. I didn't have any money, I wasn't about to steal, because I've already stolen a few things, and I accepted. (Luísa, lesbian, 22 years)

On the other hand, the commercial sex market, for some informants, showed to be a resource to live out their sexuality without the constraints imposed by other possible options:

Then after, in the day-to-day, I ended up getting to know and involving myself, because in the street where I worked las a security guard] downtown, there were people who drove cars, and they would get me, and I ended up exchanging that for my normal job, for that gay world, going out with people in the cars. (Rogério, bi, 29 years)

It is necessary to relativize, however, the cause-effect relationship apparent between the stigmatization of homosexualities and difficulties in finding work. Experience with work in professions where homosexuality was more tolerated was also cited, which shows that there are field of work, especially related to esthetics, where effeminate homosexuals find jobs and could possibly gain value because of their sexuality:

"In my profession they even ask you to be homosexual, that is hairdressing... it's more valued" (Tobias, gay, 39 years).

If we consider the three fields of the family, school, and work as some of the fundamental socializing institutions of individuals in our society and that individuals that manifest their homo/ bi/transexualities in an ostensive way could be marginalized or expelled indirectly from these institutions, we can affirm that such as a process can lead to the dissolution of social ties that correspond strongly with the process of sedentariness in our society. At the same time, the possibility of new forms of socialization open up, which are anchored in different times (night), spaces (streets and bars), type of housing (precarious) and morality (non-monogamy). These are characteristics of the nomadic urban lifestyle described before.

Distancing oneself from school and work goes closely with distancing from the family of 
origin, something that can be accentuated by heterosexism in the family context, as well as by becoming part of friendship groups with similar values, that play a fundamental role of support for a way of life seen as deviant.

The experience of living close to a group of friends enables the experiences of dissident sexualities, away from the watchful eyes of surveillance of the family, as was pointed out earlier (Parker, 2002). But the exercise of a "freer" sexuality is not the only thing that emerges due to this distancing: other forms of living deemed deviant are also facilitated, especially the use of psychoactive substances. These appear frequently, as their use can be associated with the exercise of their sexualities, connected through a search for the instensification of both types of pleasure, which intersect:

No, I was never like, I am not going to say that I never, I was like that, I had crazy relationships, but not doing it like that, it was more kissing, those things of the party. I smoked one and was crazy partying, and with the cachaça [a rum derivative]. Then I would get really crazy with my friends, and we left the party. (Wilson, bi, 20 years)

"Sometimes I slept on the streets only when I was drunk, I was binging, not because I did not have another option. If I like someone, and the person is in the street, I stay in the street" (João, gay, 32 years).

"When you're on crack its crazy, then you go out with whomever. When you use drugs, if you are along, you go out. That how it is with me at least, drugs make me horny, you understand?" (Tobias, gay, 39 years).

Experiences with drug use are presented as marked by intense use, associated with a sense of "losing oneself" and of abstinence or mild use, associated with having "control over oneself". As we saw earlier, Maffesoli (2001) defined the antinomy of nomadism-sedentariness as tied at the same time to a need for security and the desire for detachment, a desire that involves ruptures in what form of order. Moments of intensive or mild drug use, therefore, could be understood as part of the same process of alternating between sedentariness and nomadism. There are for many LBGT an inverse association between the orgiastic and sedentary life, which is related to the triangular institutions of school/family/work: the more one delves into the nomadic life, the more difficult it is to maintain relationships traditionally lived in those contexts:

"Like that, because I started to get acquainted with the party, those things. I started to lose, like, I began to become rebellious" (Wilson, bi, 20 years).

Beyond becoming a part of the orgiastic world, other factors emerge as relevant for understanding the involvement with illicit drugs, which can be related to homo/bi/transexualities. One of these factors is related to the presumed increase in going to bars and nightclubs as a way to seek friendship or affective-sexual relations. This might be due to the situation of discrimination suffered and by the lack of acceptance in the family, which could facilitate the abuse of alcohol and other psychoactive substances, frequently found in such spaces:

I started to work at a gay nightclub, I was there working for a year, and it was there that I ran into cocaine. Then I involved myself... Sniffing all day, because it was part of the nighttime routine, you know how that works, right? (Rogério, bi, 29 years)

The abuse of psychoactive drugs ${ }^{3}$ also appears to be related to stigma associated to homo/ bi/transexualities to mitigate the suffering caused by discrimination or as a way to diminish self-censorship of one's sexual orientation, as a function of the internalization of stigma:

From that anguish that I had within me that I could not could not have an orgasm with a man, why when my husband touched me I

3 North American studies estimate that the LGBT population has a higher likelihood of abusing illicit drugs, with an incidence two to three times higher than the heterosexual population controlling for age and income bracket (Bux, 1996; Jordan, 2000). In Brazil, Terto (2002), considers that "little is known about how the effects of the stress of living in a society with so many prejudices against homosexuality affect the mental and physical health of homosexuals", which call for local studies "about how depression, destructive attitudes and drug use, among others factors, are related to the difficulties of living with a sexual orientation different from the dominant". 
felt nausea, you understand? So then I fled from him, and I would stay four, five days in the streets doing drugs, and I returned and that life was there, like that crazy. (Elaine, lesbian, 38 years)

The trajectory of our informants show that homo/bi/transexuality and the use of psychoactive drugs were interrelated in their lives, related to and contributing to the nomadic socialization mentioned before, based on a nocturnal life, in the occupation of public spaces, in a distancing from the family of origin and in engaging in eventual affective ties.

Again, it is important to highlight that such trajectories should not be evaluated from the point of view of giving essential value to residence, security, or to the permanence of ties because we risk considering the lived experience of these people from the perspective of error or deviance. Notably, it was precisely this point of view that allowed for the establishment of hegemonic policies for intervention for homeless people, which aimed to make them sedentary, following the ideal of necessarily having a fixed home and occupation. This is shared by so many policies that prioritized disciplinary control in an explicit way (hygienists), as well as by some policies based on acknowledgement of the human rights of the homeless, which include the fight for the right to employment and a residence as essential.

If recognition of the right to nomadic sociability of LGBT homeless people is fundamental, so is the recognition of the multiple vulnerabilities that cross their everyday life, both of which are present movements in constant tension in the multicultural conception of human rights, which were summed up well by Souza Santos (1997) in his renown affirmation that "people and social groups have the right to be equals when difference makes them inferior and the right to be different when equality mischaracterizes them" (p. 122). Some of these vulnerabilities appear frequently in our field work, as in the case of vulnerability to violence and to health problems. In line with the theme of this article, however, we will focus here on one of the possible health problems for this segment of the homeless population: that relating to HIV/AIDS infection.

\section{Vulnerability to HIVIAIDS}

The results of our study confirm our hypotheses based on the existing literature, which points to a greatly heightened vulnerability to HIV/AIDS in this segment of the population. This is especially true if we look to the plain of social vulnerability, which is related with factors such as disrespect for human rights, including the right to education and to employment, a political and cultural context marked by discrimination and violence, the difficulty of attain adequate housing and to access consumer goods (Ayres, França, Calazans, \& Salleti, 1999). These factors are omnipresent in the trajectories of the informants in this study. Resorting to commercial sex and drug abuse as a result of the process of discrimination suffered also point to an increased vulnerability in its social plain.

Among respondents, five spontaneously reported having HIV or having already developed AIDS, even though this theme was not directly addressed in the interview. The other six interviewees were not asked about the subject, and they did not talk about their serostatus. All informants with HIV believed to have been infected through sexual transmission. In one of the cases, including Tobias (gay, 39 years), it is possible to conjecture about whether HIV infection occurred before he was living in the streets because he narrated having had a steady partnership for several years with a partner who died because of AIDS and with whom he had unprotected sex. In other cases, it was not possible to make this type of conjecture.

Finding out about being HIV positive or having AIDS and its relationship with homelessness can be interpreted through the same perspective of the "vicious cycle" mentioned earlier: homelessness seems to be directly or indirectly responsible for being infected or for the development of the illness, at the same time that the emotional impact of this discovery appears to be a factor that predisposes one to remain homeless. This was perceived in several narratives:

That's when I got sick. I stayed 40 days in a bed. I am someone who should weigh $90 \mathrm{~kg}$, and I got be $45 \mathrm{~kg}$. Then I went through a hospital, I went through another one. They 
always said the same thing to me, but internally I thought it could not be that. I could not eat, it was diarrhea, I ate and ran to the bathroom. That's when I found a doctor; she said "I am going to do an STD test". I said, "No problem, you can do it". Then that's it. There it was, I had known the drugs, then I sank. I took a hard blow, because I lost my husband, lost my mother, now that disease? What else is left? Nothing more. Everything I had was over. Defined. (Antônio, gay, 30 years)

It's just that I found out after I took some three tests because I could not believe that I was. The day I discovered that I had HIV and Hepatitis $B$ together, I fell into depression, I was left without knowing what to do. (Rogério, bi, 29 years)

I also got a bit sick, right? I have a health problem, and also got sick. I have the problem of HIV, have it for nine years, HIV, that's when I began... I was a little depressive, then I fell into the drugs, I used crack, then I started to get sick. (Nega, gay, 32 years)

The difficulties with treatment related to the lack of linkage to the health services and with keeping antiretroviral medications, as described in the literature, also appear incisively in the narratives:

"Look,I'llbesincere; Ibegantotaketreatment and stopped. I think I have to go back on it. For now I'm fine" (Rogério, bi, 29 years).

Interviewer: You managed to go on treatment correctly? Tobias: Almost, I had some days I didn't. Interviewer: Did you lose your medication? Tobias: I have. Interviewer: Living in the street is a barrier how? Tobias: It's horrible, you don't have a place to keep it, there medication that goes in the refrigerator. Not now, now I am more... Interviewer: How did you do it, did you leave it in the shelter? Tobias: I always have a bag, I have it in my bag, it's always all together. Interviewer: And the one for the refrigerator? Tobias: I never used the one for the refrigerator. In the beginning, I took thirty pills a day; today I take two. You can see it diminished a lot. Interviewer: Do you think the situation of living in the street disrupts treatment? Tobias: A lot. I am crazy to leave this situation in the streets, I am going to get out of it, guy, God willing. (Tobias, gay, 39 years)

Interviewer: You stopped using your medication? Nega: In the street. Then I went to check out my CD-4, the CD-4 had to be at three hundred and fifty, mine was a four hundred and eighty. The doctor said: "My, I've never seen a CD-4 like that, so high". She said, "Look, the Ministry of Health now has a study for people with their CD-4 less than three hundred and fifty, if you have three hundred and fifty, you can 't prescribe the medication". Mine was at four hundred and eighty... (Nega, gay, 32 years)

The results show the need to expand access to health services for this segment, which implies the challenges previously described by other authors, as much because of the situation of homelessness and because of the homo/bi/ transexuality of this population. In the case of living in the streets, the promotion of inclusion of this segment of the population should favor linkage to health services; combating the bureaucratic norms of many health institutions that involve the demand for documents for identification and proof of residence, and overcoming the resistence of health professionals, principally related to issues of hygene, which is considered inadequate for many homeless people (Carneiro et al., 1998; Dantas, 2007). But there are also several types of barriers related to the acceptance of homo/bi/transexualities, which are subject to discrimination in receiving services. This can be seen, for example, in the disrespect demonstrated by not using the social name of transvestites and transgender women, as well as the lack of attention for the specificities of their health beyond the area of STDs and AIDS. This is what Terto (2002) points to, referring to the mental health problems that result from suffering from discrimination.

In the specific case of HIV/AIDS, it is important to expand access to testing, counseling, and treatment services for the LGBT homeless population. With regards to antiretroviral treatment, building partnerships with other institutions in sectors that provide services to this segment of the population, such as shelters and 
halfway homes, is an indispensible strategy to guarantee the continuation of treatment.

The nomadic character of the population we studied reinforces the necessary expansion of Family Health Teams specifically focused on this segment and its needs (Carneiro, Jesus, \& Crevelim, 2010) and of the implantation of programs in large cities to address the abuse of psychoactive substances in the form of "Street Clinics" (Nery \& Valério, 2010), which are mobile units with multi-professional teams that service this field, usually adopting harm reduction as a central strategy.

\section{Conclusion}

The analysis of the life trajectories of our homeless informants shows evidence of a nomadic form of sociability, associated with a distancing from ties with employment, family and school to living in the streets and the frequent use of psychoactive drugs. Although this type of sociability can be related to the context of heterosexist prejudice in families, school, and work environments, the trajectories of these people also show resistance to ideas of fixation present in these institutions, which requires the attention of public policymakers to an understanding and respect necessary so that services targeted to this segment of the population do not mollify the singularities of their trajectories.

The concept of vulnerability was useful for understanding the difficulties narrated by informants, especially for establishing links between their individual trajectories and forms of heterosexist domination present in diverse contexts of Brazilian society, which has a relative absence of programmatic actions for this population. Attention to diverse vulnerabilities observed stands as a result of the full recognition of human rights intended by Brazilian legislation, but must involve, as noted, the recognition of the right to forms of sociability that break with the ideal of bourgeois life and carry with them the brand of life that occurs at night and in public spaces, uncertain housing, fortuitous relationships, the use of psychoactive substances, and the frequent recourse to commercial sex.
Regarding HIV/AIDS, this study shows that homelessness is configured as a situation that accumulates a synergy of situations of discrimination and violence, which strongly interrelated, increase vulnerability to HIV infection and illness due to AIDS. The trajectories of many of the informants of this study show that prejudice and discrimination associated with dissident sexual orientations and gender identities are predisposing factors for the condition of homelessness experienced by them, given their strong presence in the institutions of the family, school and work, making it difficult to garner support from the family in situations of financial crisis and to access better-paying jobs, which in turn favors participation in the commercial sex market. These trajectories coupled with homophobic violence in the streets, drug abuse, and programmatic vulnerability resulting from the precarious policies of assistance in this area proved to be elements closely associated with increased vulnerability to HIV/AIDS.

Beyond individual and social vulnerabilities to HIV infection, which is augmented in this population due to the context described above, the dense descriptions obtained in the interviews allowed us to observe the difficulties in following adequate treatment, especially when it involves the use of antiretrovirals. This is due principally to the nomadic lifestyles of this segment of the population, which makes it difficult to access health services as well as to keep and use medications adequately.

Public policy should consider the specificities of this population - as much in the area of health as in the areas of education, housing, and social assistance - and take into consideration the nomadic character of these people's lifestyles. This nomadic nature questions the propriety of the processes of care and psychosocial attention that still dominate the curricular training of psychologists (centered on the individual and outpatient clinic) as well as decontextualized psychological theories common in courses in the areas of medicine, nursing, social work and pedagogy. 


\section{References}

Ayres, J. R., França, I., Jr., Calazans, G. J., \& Salleti, H. C., Filho (1999). Vulnerabilidade e prevenção em tempos de AIDS. In R. M. Barbosa \& R. Parker (Orgs.), Sexualidades pelo avesso: $\mathrm{Di}$ reitos, identidades e poder (pp. 49-720). Rio de Janeiro, RJ: Editora 34.

Bardin, L. (2004). Análise de conteúdo. Lisboa, Portugal: Edições 70.

Brito, V. O. C., Parra, D., Facchini, R., \& Buchalla, C. M. (2007). Infecção pelo HIV, hepatites B e $\mathrm{C}$ e sífilis em moradores de rua, São Paulo. Revista de Saúde Pública, 41(2), 47-56.

Bux, D. A. (1996). The epidemiology of problem drinking in gay men and lesbians: A critical review. Clinical Psychology Review, 16(4), $277-$ 298.

Carneiro, N., Jr., Jesus, C. H., \& Crevelim, M. A. (2010). A Estratégia Saúde da Família para a equidade de acesso dirigida à população em situação de rua em grandes centros urbanos. Saúde e Sociedade, 19(3), 709-716.

Carneiro, N., Jr., Nogueira, E. A., Lanferini, G. M., Ali, D. A., \& Martinelli, M. (1998). Serviços de saúde e população de rua: Contribuição para um debate. Saúde e Sociedade, 7(2), 47-62.

Cochran, B. N., Stewart, A. J., Ginzler, J. A., \& Cauce, A. M. (2002). Challenges faced by homeless sexual minorities: Comparison of gay, lesbian, bisexual, and transgender homeless adolescents with their heterosexual counterparts. American Journal of Public Health, 92(5), 773-777.

Costa, A. P. M. (2005). População em situação de rua: Contextualização e caracterização. Textos \& Contextos, 4(1), 1-15.

Dantas, M. (2007). Construção de políticas públicas para população em situação de rua no município do Rio de Janeiro: Limites, avanços e desafios (Dissertação de mestrado, Escola Nacional de Saúde Pública, Rio de Janeiro, RJ, Brasil).

De Lucca, D. (2007). A rua em movimento - Experiências urbanas e jogos sociais em torno da população de rua (Dissertação de mestrado, Faculdade de Filosofia, Letras e Ciências Humanas, Universidade de São Paulo, SP, Brasil).

Deleuze, G., \& Guattari, F. (1995). Mil platôs: Capitalismo e esquizofrenia (Vol. 5). São Paulo, SP: Editora 34.
Dunne, G. A., Prendergast, S., \& Telford, D. (2002). Young, gay, homeless and invisible: A growing population? Culture, Health \& Sexuality, 4(1), 103-115.

Escorel, S. (1999). Vidas ao léu: Trajetórias de exclusão social. Rio de Janeiro, RJ: Fundação Oswaldo Cruz.

Frangella, S. M. (2004). Corpos urbanos errantes: Uma etnografia da corporalidade de moradores de rua em São Paulo (Tese de doutorado, Instituto de Filosofia e Ciências Humanas, Universidade Estadual de Campinas, SP, Brasil).

Green, J. N. (2000). Além do Carnaval: A homossexualidade masculina no Brasil do século $X X$. São Paulo, SP: Universidade Estadual Paulista Júlio de Mesquita Filho.

Guattari, F. (1992). Caosmose: Um novo paradigma estético. São Paulo, SP: Editora 34.

Hall, S. (2003). A identidade cultural na pós-modernidade. Rio de Janeiro, RJ: DP\&A.

Hyde, J. (2005). From home to street: Understanding young people's transitions into homelessness. Journal of Adolescence, 28(2), 171-183.

Meta Instituto de Pesquisa de Opinião. (2008). Relatório final do primeiro censo nacional e pesquisa amostral sobre a população em situação de rua. Porto Alegre, RS: Autor.

Joint United Nations Programme on HIV/AIDS. (2006). Report on the global AIDS epidemic. Geneva, Switzerland: Author.

Jordan, K. M. (2000). Substance abuse among gay, lesbian, bisexual, transgender, and questioning adolescents. School Psychology Review, 29, 201-206.

Kennedy, M. (1991). Homeless and runaway youth mental health issues: No access to the system. Journal of Adolescent Health, 12, 576-579.

Kipke, M. D., O’Connor, S., Palmer, R., \& Mackenzie, R. G. (1995). Street youth in Los Angeles: Profile of a group at high risk for human immunodeficiency virus infection. Archives of Pediatrics \& Adolescent Medicine, 149(5), 513-519.

Kruks, G. (1991). Gay and lesbian homeless/street youth: Special issues and concerns [Special issue]. Journal of Adolescent Health, 12(7), 515518.

Lovisi, G. M. (2000). Avaliação de distúrbios mentais em moradores de albergues públicos das 
cidades do Rio de Janeiro e Niterói (Tese de doutorado, Escola Nacional de Saúde Pública, Fundação Oswaldo Cruz, Rio de Janeiro, RJ, Brasil).

Maffesoli, M. (2001). Sobre o nomadismo: Vagabundagens pós-modernas. Rio de Janeiro, RJ: Record.

Malta, M., Petersen, M. L., Clair, S., Freitas, F., \& Bastos, F. I. (2005). Aderência à terapia anti-retroviral: Um estudo qualitativo com médicos no Rio de Janeiro. Cadernos de Saúde Pública, 21(5), 1424-1432.

Milburn, N. G., Ayala, G., Rice, E., Batterham, P., \& Rotheram-Borus, M. J. (2006). Discrimination and exiting homelessness among homeless adolescents. Cultural Diversity and Ethnic Minority Psychology, 2(4), 658-672.

Nery, A., Filho, \& Valério, A. L. R. (Orgs.). (2010). Módulo para capacitação dos profissionais do projeto consultório de rua. Brasília, DF: Secretaria Nacional de Políticas sobre Drogas.

Parker, R. (2002). Abaixo do Equador. Rio de Janeiro, RJ: Record.

Pennbridge, J. N., Freese, T. E., \& Mackenzie, R. G. (1992, Fall). High-risk behaviors among male street youth in Hollywood, California. AIDS Education and Prevention (Suppl.), 24-33.

Perlongher, N. (1987). O negócio do michê: Prostituição viril em São Paulo. São Paulo, SP: Brasiliense.

Perrot, M. (2009). Maneiras de morar. In P. Ariés \& G. Duby (Orgs.), História da vida privada: Da Revolução Francesa à Primeira Guerra (Vol. 4, pp. 284-302). São Paulo, SP: Cia. das Letras.

Pfeifer, R. W., \& Oliver, J. (1997). A study of HIV seroprevalence in a group of homeless youth in Hollywood, California. The Journal of Adolescent Health, 20(5), 339-342.

Rew, L., Whittaker, T. A., Taylor-Seehafer, M. A., \& Smith, L. R. (2005). Sexual health risks and protective resources in gay, lesbian, bisexual, and heterosexual homeless youth. Journal for Specialists in Pediatric Nursing, 10(1), 11-19.

Rosenthal, D., Mallett, S., \& Myers, P. (2006). Moving out moving on: Young people's pathways in and through homelessness in Melbourne. Australian and New Zealand Journal of Public Health, 30(3), 281-285.
Rotheram-Borus, M. J., \& Koopman, C. (1991). Sexual risk behaviors, AIDS knowledge, and beliefs about AIDS among runaways. American Journal of Public Health, 81(2), 208-210.

Silva, L. A. (2000). Cartografia da atenção à saúde da população de rua na cidade de São Paulo: Um estudo exploratório (Dissertação de mestrado, Pontifícia Universidade Católica de São Paulo, SP, Brasil).

Sondheimer, D. L. (1992). HIV infection and disease among adolescents. In R. J. Diclemente (Ed.), Adolescents and AIDS: A generation in jeopardy (pp. 71-85). Newbury Park, CA: Sage.

Souza Santos, B. (1997). Por uma concepção multicultural de direitos humanos. Lua Nova - Revista de Cultura e Política, 39, 105-124.

Sugerman, S. T., Hergenroeder, A. C., Chacko, M. R., \& Parcel, G. S. (1991). Acquired immunodeficiency syndrome and adolescents. Knowledge, attitudes, and behaviors of runaway and homeless youth. American Journal of Diseases of Children, 145(4), 431-436.

Terto, V., Jr. (2002). Homossexualidade e saúde: Desafios para a terceira década de epidemia de HIV/AIDS. Horizontes Antropológicos, 17, 147-158.

Unger, J. B., Kipke, M. D., Simon, T. R., Montgomery, S. B., \& Johnson, C. J. (1997). Homeless youths and young adults in Los Angeles: Prevalence of mental health problems and the relationship between mental health and substance abuse disorders. American Journal of Community Psychology, 25(3), 371-394.

Whitbeck, L. B., Chen, X., Hoyt, D. R., Tyler, K., \& Johnson, K. (2004). Mental disorder, subsistence strategies, and victimization among gay, lesbian, and bisexual homeless and runaway adolescents. The Journal of Sex Research, 41(4), 329-342. 